\title{
Impact of dietary calcium tetraborate supplementation on the mineral content of egg and eggshell of laying quails
}

\author{
Seda Iflazoglu Mutlu 1,*, Ulku Gulcihan Simsek ${ }^{2}$, Sera Iflazoglu ${ }^{3}$, Aysen Yilmaz ${ }^{3}$, Muhsin Mutlu 4 and Pinar \\ Tatli Seven ${ }^{1}$ \\ ${ }^{1}$ Department of Animal Nutrition and Nutritional Diseases, Faculty of Veterinary Medicine, Firat University, Elazig, \\ Turkey. \\ 2 Department of Animal Science, Faculty of Veterinary Medicine, Firat University, Elazig, Turkey. \\ ${ }^{3}$ Department of Chemistry, Middle East Technical University, Ankara, Turkey. \\ ${ }^{4}$ Department of Food Hygiene and Technology, Faculty of Veterinary Medicine, Firat University, Elazig, Turkey.
}

GSC Biological and Pharmaceutical Sciences, 2021, 15(01), 018-026

Publication history: Received on 25 February 2021; revised on 30 March 2021; accepted on 02 April 2021

Article DOI: https://doi.org/10.30574/gscbps.2021.15.1.0090

\begin{abstract}
Boron (B) is a trace element that plays an important role in the mineral, cell membrane, hormone, and enzyme metabolism of animals and humans. The aim of this study was to examine the effect of dietary calcium tetraborate $\left(\mathrm{CaB}_{4} \mathrm{O}_{7}\right)$ supplementation on the mineral composition of egg content and eggshell of laying quails. For this purpose, a total of 20 male and 40 female quails, 6-week-old, were equally divided into 2 groups (control and additive groups) in 5 replicates ( 6 birds/replicate) and given $\mathrm{CaB}_{4} \mathrm{O}_{7} 300 \mathrm{mg} / \mathrm{kg}$ feed in additive group. The experiment was conducted for 56 days. The eggs were collected and the mineral composition [B, calcium (Ca), magnesium (Mg), sodium (Na), iron (Fe), potassium $(\mathrm{K})$, manganese $(\mathrm{Mn})$, copper $(\mathrm{Cu})$, zinc $(\mathrm{Zn})]$ of egg content and eggshell samples were determined at the end of the experiment in randomly collected 6 eggs per group. Results of this study indicated dietary supplementation of $\mathrm{CaB}_{4} \mathrm{O}_{7}$ increased $\mathrm{Mg}(\mathrm{P}<0.01)$, $\mathrm{Na}(\mathrm{P}<0.01)$, and $\mathrm{K}(\mathrm{P}<0.05)$ contents of edible parts of eggs compared to the control group, but $\mathrm{B}$ concentration were not determined in edible parts of eggs in both groups. Moreover, $\mathrm{B}(\mathrm{P}<0.01), \mathrm{Mg}$ $(\mathrm{P}<0.01), \mathrm{Na}(\mathrm{P}<0.01), \mathrm{Fe}(\mathrm{P}<0.01), \mathrm{K}(\mathrm{P}<0.05), \mathrm{Cu}(\mathrm{P}<0.05)$ and $\mathrm{Zn}(\mathrm{P}<0.01)$ of eggshell were higher in the additive group than control. There were also significant correlations between examined minerals both edible and eggshell parts of the eggs. It may be concluded that supplementing diets with $\mathrm{CaB}_{4} \mathrm{O}_{7}$ could improve Ca metabolism, producing eggs enriched in minerals, promoting $\mathrm{B}, \mathrm{Mg}, \mathrm{Na}, \mathrm{Fe}, \mathrm{K}, \mathrm{Cu}$, and $\mathrm{Zn}$ deposition in eggshells, and improving eggshells quality. The effective B supplementation doses for functional egg production could be determined and B could be advantageous in terms of beneficial physiological effects.
\end{abstract}

Keywords: Calcium tetraborate; Egg; Eggshell; Mineral; Quail

\section{Introduction}

In today's conditions where industrial food consumption is common, egg consumption is important for a healthy life, considering it is a natural nutrient and its rich vitamin and mineral content. Egg is a very valuable food source with high protein quality among animal products, rich in vitamins (A, D, E and B groups) and mineral substances [calcium (Ca), potassium (K), sodium (Na)] [1]. It also contains all essential trace elements, including copper (Cu), iron (Fe), magnesium (Mg), manganese (Mn), selenium (Se), and zinc ( $\mathrm{Zn})$, and the egg yolk provides the largest contribution to the Fe and Zn requirement [2]. The nutrient composition of the egg can be changed by various adjustments to the nutrient composition of the ration. For example; it has been reported that as a result of the consumption of legume forage plants such as alfalfa by free-range chickens, the obtained eggs and chicken meat can be rich in omega 3,6 ,

\footnotetext{
${ }^{*}$ Corresponding author: Seda Iflazoglu Mutlu

Department of Animal Nutrition and Nutritional Diseases, Faculty of Veterinary Medicine, Firat University, Elazig, Turkey.
} 
carotene and vitamin $\mathrm{E}$ [3]. In this context, vitamins (A, D , E and C), mineral substances (iodine, $\mathrm{K}, \mathrm{Se}$ and Fe), omega 3, and conjugated linoleic come to the fore as functional feed additives that provide transition to the product. In addition, the enrichment of eggs with colour substances (carotenoid compounds) such as lutein and lycopene has been on the agenda recently. In recent years, table eggs enriched with vitamins (A and E), omega-3 and trace minerals (Se, I) have now taken their place on the market shelves $[4,5]$.

The food quality of eggs is largely dependent on the diet and the health of the animal [6]. Eggs can be enriched with different foods. It is possible to produce "functional eggs" enriched with one or more functional components according to the demands of the consumers [7]. Functional food should contain higher amounts of some compounds that positively affect human health. When naturally not present in sufficient quantities, functional foods should be further enriched with these compounds. The nutritional profile of eggs can be easily enriched with omega-3, minerals and vitamins by adding these compounds to the diet. These compounds are benefit health and also reduce the risk of some serious chronic diseases [8].

Boron is a semiconductor element that has the symbol "B" in the periodic table and shows properties between metal and non-metallic [9]. It is now known that B is an essential nutrient component for humans and animals [10]. B meets most criteria as a basic nutrient. Because of its low atomic weight, it binds to organic compounds in ways that affect biological function [11]. B, which is not found in free form in the organism, generally exists as organic B compounds bound to sodium and oxygen elements in the form of boric acid $\left(\mathrm{B}(\mathrm{OH})_{3}\right)$ or borate $\left(\mathrm{B}(\mathrm{OH})_{4}\right)$. These compounds occur in human, animal and plant tissues $[12,13,14]$. The relationship of $B$, which has an important place in living metabolism, with other nutrients is also important. It has been stated that B has a role in the utilization of minerals effective in bone metabolism such as $\mathrm{Ca}, \mathrm{Mg}$, and interacts with phosphorus, $\mathrm{Cu}$, methionine, arginine and vitamin $\mathrm{D}[14,15]$. The aim of the present study was to assess impact of dietary $\mathrm{CaB}_{4} \mathrm{O}_{7}$ supplementation on the mineral content of egg and eggshell of laying quails.

\section{Material and methods}

\subsection{Experimental design and diet}

The ethics committee for the animals used in this study was approved by Firat University, Animal Experiments Local Ethics Committee (2020/11). A total of 60 (6-week-old) quails were used. Quails were divided into 2 groups with 5 replications per group and 4 females +2 males per repetition: (i) control group ( $0 \mathrm{mg}$ of $\mathrm{CaB}_{4} \mathrm{O}_{7}$ per $\mathrm{kg}_{\mathrm{g}}$ of diet), (ii) $\mathrm{CaB}_{4} \mathrm{O}_{7}$ group (300 mg of $\mathrm{CaB}_{4} \mathrm{O}_{7}$ per $\mathrm{kg}$ of diet, $22.14 \%$ elemental $\mathrm{B} / \mathrm{kg}$ diet). The quails were housed in a controlled environment with $16 \mathrm{~h}$ light: $8 \mathrm{~h}$ dark/day program. Feed and water were given ad libitum to the quails. The basal diet was prepared according to NRC [16]. The nutrient composition of the diet used in the study was determined [17, 18, 19]. Diet compositions and nutrient contents were shown in Table 1 . The experiment lasted 8 weeks. At the end of the study, 6 eggs were taken from each group together with the feed sample. Eggs were stored at $+4^{\circ} \mathrm{C}$ until analysis.

Table 1 Ingredients and nutrient composition of experimental diet (\%) $)^{a}$

\begin{tabular}{|l|l|}
\hline Ingredients & $\mathbf{\%}$ \\
\hline Maize & 56.00 \\
\hline Soybean meal $(44 \% \mathrm{CP})$ & 26.80 \\
\hline Sunflower meal $(28 \% \mathrm{CP})$ & 1.20 \\
\hline Wheat bran & 2.10 \\
\hline Sunflower oil & 2.35 \\
\hline Sodium chloride & 0.35 \\
\hline L-Lysine hydrochloride & 0.15 \\
\hline L-Treonine & 0.10 \\
\hline Sodium bicarbonate & 0.20 \\
\hline DL-Methionine & 0.10 \\
\hline Vitamin-Mineral premix ${ }^{\mathrm{b}}$ & 0.35 \\
\hline
\end{tabular}




\begin{tabular}{|l|l|}
\hline Ground limestone & 8.00 \\
\hline Dicalcium phosphate & 2.30 \\
\hline Total & 100 \\
\hline Nutritional composition & \\
\hline Dry matter, \% & 90.50 \\
\hline Crude protein, \% & 17.50 \\
\hline Crude cellulose, \% & 3.65 \\
\hline Ether extract, \% & 4.00 \\
\hline Crude ash, \% & 13.58 \\
\hline Phosphorus ${ }^{c}$ & 0.35 \\
\hline Lysinec & 1.00 \\
\hline Threonine $^{c}$ & 0.74 \\
\hline ME, kcal $/ \mathrm{kgc}^{c}$ & 2750 \\
\hline
\end{tabular}

${ }^{a} \mathrm{CaB}_{4} \mathrm{O}_{7}$ (300 $\mathrm{mg} \mathrm{CaB}_{4} \mathrm{O}_{7}$ per kg diet) was added to the basal diet. bVitamin-mineral premix (per 1kg): vitamin A, 8000 IU; vitamin $\mathrm{D}_{3}, 3000 \mathrm{IU}$; vitamin E, $25 \mathrm{IU}$; menadione, $1.5 \mathrm{mg}$; vitamin $\mathrm{B}_{12}, 0.02 \mathrm{mg}$; biotin, $0.1 \mathrm{mg}$; folacin, $1 \mathrm{mg}$; niacin, $50 \mathrm{mg}$; pantothenic acid, $15 \mathrm{mg}$; pyridoxine, $4 \mathrm{mg}$; riboflavin, $10 \mathrm{mg}$; and thiamin, $3 \mathrm{mg}$ copper (copper sulphate), $10 \mathrm{mg}$; iodine (ethylenediamine dihydriodide), $1.0 \mathrm{mg}$; iron (ferrous sulphate monohydrate), 50 mg; manganese (manganese sulphate monohydrate), $60 \mathrm{mg}$; and zinc (zinc sulphate monohydrate), $60 \mathrm{mg}$, selenium (sodium selenite), $0.42 \mathrm{mg}$. cCalculated.

Table 2 Mineral composition of diet

\begin{tabular}{|l|l|}
\hline Mineral & \% \\
\hline $\mathrm{B}$ & 0.125 \\
\hline $\mathrm{Ca}$ & 6.335 \\
\hline $\mathrm{Mg}$ & 0.280 \\
\hline $\mathrm{Na}$ & 0.428 \\
\hline $\mathrm{Fe}$ & 0.023 \\
\hline $\mathrm{K}$ & 0.919 \\
\hline $\mathrm{Mn}$ & 0.016 \\
\hline $\mathrm{Cu}$ & 0.001 \\
\hline $\mathrm{Zn}$ & 0.020 \\
\hline
\end{tabular}

\subsection{Preparation and characterization of calcium tetraborate}

$\mathrm{CaB}_{4} \mathrm{O}_{7}$ as a powder form was synthesized by solid-state reaction method. For synthesis of the $\mathrm{CaB}_{4} \mathrm{O}_{7} \mathrm{was} \mathrm{used}_{\mathrm{CaCO}}$ (98.5\% pure, Merck), $\mathrm{H}_{3} \mathrm{BO}_{3}$ (99.5\% pure, Merck), and $\mathrm{CO}\left(\mathrm{NH}_{2}\right)_{2}$ (99.5\% pure, Merck). The obtained CaB $\mathrm{O}_{7} \mathrm{samples}$ were characterized by XRD method. Analysis of the crystalline structure was performed by using Rigaku MiniFlex X-ray diffractometer (XRD) with $\mathrm{Cu}-\mathrm{K} \alpha$ radiation $\left(\lambda=1,54056 \AA\right.$, in the $2 \theta$ range of $3^{\circ}-60^{\circ}$ at $2^{\circ} / \mathrm{min}$ scan rate). The XRD of $\mathrm{CaB}_{4} \mathrm{O}_{7}$ was shown in Figure 1. According to the XRD results in Figure 1, the most intense peaks in the diffractogram overlap with the JCPDS (Card No: 31-0253) card. In this case, $\mathrm{CaB}_{4} \mathrm{O}_{7}$ compound has been synthesized successfully [20]. 


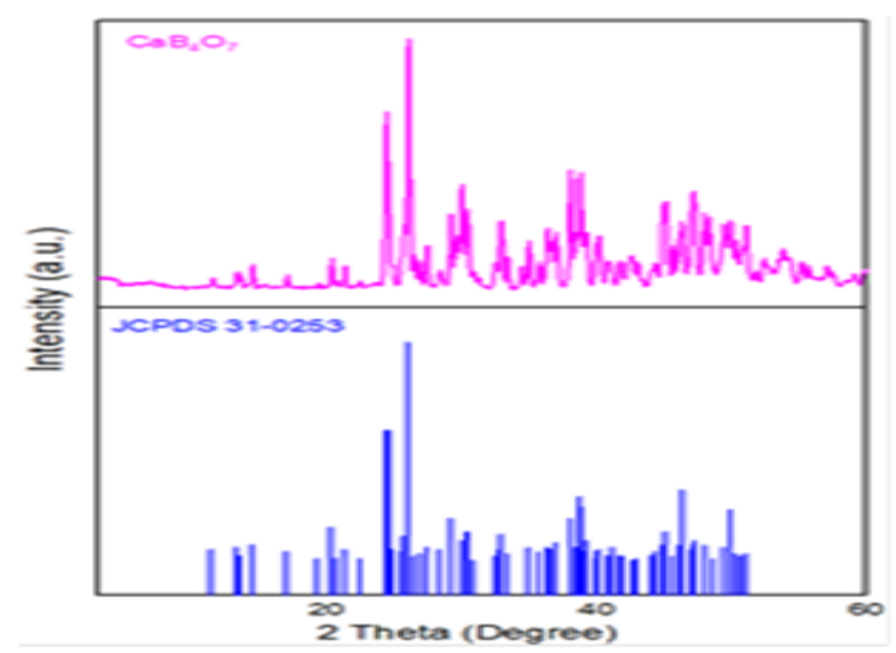

Figure $1 \mathrm{XRD}$ patterns of $\mathrm{CaB}_{4} \mathrm{O}_{7}$ compound

\subsection{Mineral determination}

\subsubsection{Sample preparation}

Eggshells were dried at $100^{\circ} \mathrm{C}$ in a NÜVE-FN 500 brand oven until they reached a constant weight. The dehumidified eggshells were mixed in a mortar and powdered and homogeneous. Egg inside was placed in a $50 \mathrm{~mL}$ beaker and mixed in an IKA-RTO brand magnetic mixer at 300-400 rpm speed, and the yellow and white parts were mixed thoroughly and homogeneous. The feed samples were dried in a NÜVE-FN 500 brand oven at $100{ }^{\circ} \mathrm{C}$ until they reached a constant weight. The value of metals in the homogenized eggshell, internal egg and feed samples were determined with the ICPOES device after microwave acidic extraction pretreatment.

\subsubsection{Inductively coupled plasma optical emission spectroscopy (ICP-OES) analysis}

Homogenized eggshell, internal egg and feed samples weighed approximately $0.1 \mathrm{~g}$ together with $9 \pm 0.1 \mathrm{~mL} 65 \%(\mathrm{v} / \mathrm{v})$ nitric acid (Merck) and 3 $\pm 0.1 \mathrm{~mL} 37 \%$ (v/v) hydrochloric acid (Merck) PTFE (Polytetrafluoroethylene) is taken into microwave containers. Acidic crushing process is performed at $175 \pm 5^{\circ} \mathrm{C}$ with the CEM-Mars 6 microwave device. The EPA 3051A standard method was followed in the microwave acid digestion pretreatment. The same procedures as for the samples were done in the blank. After the samples coming out of the microwave were cooled down to room temperature $\left(22-23^{\circ} \mathrm{C}\right)$, all samples were completed to $50 \mathrm{~mL}$ with $1 \% \mathrm{HNO}_{3}$. The metal values of the egg shell, egg and feed samples which were broken by microwave were analyzed by using the Thermo-Scientific-ICAP 7000 brand ICPOES device according to the EPA 6010 D method. The calibration standards used in the analysis were prepared with $1 \%$ $\mathrm{HNO}_{3}$ just like the blank and samples. In order to prevent contamination, all vessels and apparatus used in analyzes were kept in $10 \% \mathrm{HNO}_{3}$ for 1 night and then washed thoroughly with ultrapure pure water. Reagents of analytical purity were used in the analyzes and all solutions were prepared with ultrapure distilled water from the MES MP mini pure device.

The same analytical procedures applied to egg/feed samples to ensure the validity of the results of the analyzes are also applied to certified reference materials (NIST SRM 1573a Tomato Leaves, NIST SRM 1835 Borate Ore). The analysis results of the metals included in the certified reference materials were compared with the certificate values and it was seen that the results were within the certification range. The results of the enriched quality control samples were checked according to the \% recovery value between $80-120 \%$ and it was seen that all results were within this range $[21,22]$.

\subsection{Statistical analysis}

The data were subjected to the Independent Sample T-test using the SPSS 22 package program after testing the normality with Shapiro-Wilk and homogeneity of variances with Levene's test. Moreover, Pearson's correlation analysis was used to assess the correlation between minerals. The results were considered significant at $\mathrm{P}<0.05$ [23]. 


\section{Results}

Table 3 is shown the effect of $\mathrm{CaB}_{4} \mathrm{O}_{7}$ on mineral contents of eggs. There were no significant differences in $\mathrm{Ca}$, Fe, $\mathrm{Mn}$, $\mathrm{Cu}$ and $\mathrm{Zn}$ minerals of egg content between the control and additive group ( $\mathrm{P}>0.05)$. The $\mathrm{CaB}_{4} \mathrm{O}_{7}$ was significantly affected by the levels of $\mathrm{Mg}(\mathrm{P}<0.01), \mathrm{Na}(\mathrm{P}<0.01)$ and $\mathrm{K}(\mathrm{P}<0.05)$. The addition of $300 \mathrm{mg} / \mathrm{kg} \mathrm{CaB}_{4} \mathrm{O}_{7}$ significantly increased egg $\mathrm{Mg}$, $\mathrm{Na}$ and $\mathrm{K}$ content in layer quails. In addition, the Ca content of the additive group was higher than the control group, but not significant. The amounts of B was below the detection limit of the methods used.

Table 3 Mineral contents of whole edible parts of eggs.

\begin{tabular}{|l|l|l|l|l|}
\hline Mineral & Control & $\mathbf{C a B}_{4} \mathbf{O}_{7}$ & SEM & P \\
\hline $\mathrm{B}(\mathrm{mg} / \mathrm{kg})$ & $\mathrm{ND}$ & $\mathrm{ND}$ & - & - \\
\hline $\mathrm{Ca}(\mathrm{mg} / \mathrm{kg})$ & 687.49 & 722.82 & 50.24 & 0.638 \\
\hline $\mathrm{Mg}(\mathrm{mg} / \mathrm{kg})$ & 112.36 & 147.28 & 4.22 & 0.001 \\
\hline $\mathrm{Na}(\mathrm{g} / \mathrm{kg})$ & 1.47 & 1.75 & 0.05 & 0.004 \\
\hline $\mathrm{Fe} \mathrm{(mg/kg)}$ & 28.61 & 27.90 & 1.51 & 0.752 \\
\hline $\mathrm{K}(\mathrm{g} / \mathrm{kg})$ & 1.29 & 1.44 & 0.04 & 0.026 \\
\hline $\mathrm{Mn}(\mathrm{mg} / \mathrm{kg})$ & 0.79 & 0.74 & 0.12 & 0.760 \\
\hline $\mathrm{Cu}(\mathrm{mg} / \mathrm{kg})$ & 1.05 & 1.03 & 0.06 & 0.900 \\
\hline $\mathrm{Zn}(\mathrm{mg} / \mathrm{kg})$ & 10.56 & 10.19 & 0.86 & 0.775 \\
\hline
\end{tabular}

$\mathrm{CaB}_{4} \mathrm{O}_{7}$ : Calcium tetraborate; ND: Not detected; Detection limit of: B < 1.66; SEM: Standard error of mean; P $<0.05$. Data are presented as mean and SEM.

Only $\mathrm{Ca}$ and $\mathrm{Mn}$ content measured in the eggshells were unaffected by the $\mathrm{CaB}_{4} \mathrm{O}_{7}$ supplementation (Table 4 , $\mathrm{P}>0.05$ ). The $\mathrm{B}$ content was higher in the eggshells of the animals in the additive group $(\mathrm{P}<0.01)$. Similarly, eggshells $\mathrm{Mg}(\mathrm{P}<0.01)$, $\mathrm{Na}(\mathrm{P}<0.01), \mathrm{Fe}(\mathrm{P}<0.01), \mathrm{Mn}(\mathrm{P}>0.05), \mathrm{Cu}(\mathrm{P}<0.05), \mathrm{K}(\mathrm{P}<0.05)$, and $\mathrm{Zn}(\mathrm{P}<0.01)$ content was higher in the additive group. Zinc was higher in the additive group eggshells than in the control group eggshells.

Table 4 Mineral contents of eggshells.

\begin{tabular}{|l|l|l|l|l|}
\hline Mineral & Control & $\mathbf{C a B}_{4} \mathbf{O}_{7}$ & SEM & P \\
\hline $\mathrm{B} \mathrm{(mg/kg)}$ & 16.33 & 51.02 & 4.31 & 0.001 \\
\hline $\mathrm{Ca}(\mathrm{mg} / \mathrm{kg})$ & 373.21 & 350.47 & 7.81 & 0.112 \\
\hline $\mathrm{Mg}(\mathrm{mg} / \mathrm{kg})$ & 6.86 & 8.87 & 0.34 & 0.004 \\
\hline $\mathrm{Na}(\mathrm{g} / \mathrm{kg})$ & 1.86 & 2.91 & 0.12 & 0.001 \\
\hline $\mathrm{Fe} \mathrm{(mg/kg)}$ & 9.45 & 17.34 & 1.36 & 0.003 \\
\hline $\mathrm{K} \mathrm{(g/kg)}$ & 1.15 & 1.45 & 0.06 & 0.019 \\
\hline $\mathrm{Mn}(\mathrm{mg} / \mathrm{kg})$ & 1.18 & 1.85 & 0.28 & 0.127 \\
\hline $\mathrm{Cu}(\mathrm{mg} / \mathrm{kg})$ & 2.08 & 2.84 & 0.19 & 0.020 \\
\hline $\mathrm{Zn}(\mathrm{mg} / \mathrm{kg})$ & 7.21 & 56.41 & 5.44 & 0.001 \\
\hline
\end{tabular}

$\mathrm{CaB}_{4} \mathrm{O}_{7}$ : Calcium tetraborate; SEM: Standard error of mean; $\mathrm{P}<0.05$. Data are presented as mean and SEM.

Table 5 presents the Pearson's correlation coefficients analyses among egg minerals. The results indicated that Mg had the highest correlation with $\mathrm{Na}(\mathrm{r}=0.750 ; \mathrm{P}<0.01)$ and the lowest correlation with $\mathrm{Cu}(\mathrm{r}=0.072 ; \mathrm{P}>0.05)$. Fe had the strongest correlation with $\mathrm{Mn}(\mathrm{r}=0.802 ; \mathrm{P}<0.01)$. There were positive correlations between $\mathrm{Ca}$ and $\mathrm{Fe}, \mathrm{Cu}, \mathrm{Mn}$ and negative correlation between $\mathrm{Na}$ and $\mathrm{Ca}, \mathrm{Fe}, \mathrm{Mn}$. 
Table 5 Pearson's correlation coefficients among whole egg mineral traits.

\begin{tabular}{|l|l|l|l|l|l|l|}
\hline & Na & K & Ca & Fe & Mn & Cu \\
\hline $\mathrm{Mg}$ & $0.750^{* *}$ & $0.734^{* *}$ & 0.296 & 0.274 & 0.235 & 0.072 \\
\hline $\mathrm{Na}$ & & 0.522 & -0.080 & -0.025 & -0.063 & 0.124 \\
\hline $\mathrm{K}$ & & & 0.239 & 0.050 & -0.081 & 0.113 \\
\hline $\mathrm{Ca}$ & & & & $0.593^{*}$ & 0.574 & 0.382 \\
\hline $\mathrm{Fe}$ & & & & & $0.802^{* *}$ & 0.413 \\
\hline $\mathrm{Mn}$ & & & & & & 0.338 \\
\hline
\end{tabular}

The Pearson correlation coefficients between $\mathrm{Ca}, \mathrm{Mg}, \mathrm{Na}, \mathrm{Fe}, \mathrm{K}, \mathrm{Mn}, \mathrm{Cu}, \mathrm{Zn}$ and B are shown in Table 6. Ca was negatively correlated with $\mathrm{Mg}(\mathrm{r}=-0.126), \mathrm{Na}(\mathrm{r}=-0.609, \mathrm{p}<0.05), \mathrm{Fe}(\mathrm{r}=-0.524), \mathrm{K}(\mathrm{r}=-0.555), \mathrm{Mn}(\mathrm{r}=-0.460), \mathrm{Cu}(\mathrm{r}=-0.385), \mathrm{Zn}$ $(\mathrm{r}=-0.735, \mathrm{P}<0.01)$, and $\mathrm{B}(\mathrm{r}=-0.648, \mathrm{P}<0.05)$, respectively. $\mathrm{Mg}$ was positively correlated with $\mathrm{Na}, \mathrm{Fe}, \mathrm{K}, \mathrm{Mn}, \mathrm{Cu}, \mathrm{Zn}, \mathrm{and}$ B. Moreover, Fe, K, Mn, and Cu were positively correlated with $\mathrm{Zn}$. Significant $(\mathrm{P}<0.01)$ positive correlations were found between $\mathrm{Zn}$ and $\mathrm{B}(\mathrm{r}=0.883)$.

Table 6 Pearson's correlation coefficients among mineral deposition in eggshell.

\begin{tabular}{|l|l|l|l|l|l|l|l|l|}
\hline & $\mathbf{M g}$ & $\mathbf{N a}$ & $\mathbf{F e}$ & $\mathbf{K}$ & $\mathbf{M n}$ & $\mathbf{C u}$ & $\mathbf{Z n}$ & $\mathbf{B}$ \\
\hline $\mathrm{Ca}$ & -0.126 & $-0.609^{*}$ & -0.524 & -0.555 & -0.460 & -0.385 & $-0.735^{* *}$ & $-0.648^{*}$ \\
\hline $\mathrm{Mg}$ & & $0.759^{* *}$ & $0.623^{*}$ & $0.626^{*}$ & 0.396 & 0.564 & 0.408 & 0.517 \\
\hline $\mathrm{Na}$ & & & $0.817^{* *}$ & $0.863^{* *}$ & 0.323 & $0.667^{*}$ & $0.715^{* *}$ & $0.672^{*}$ \\
\hline $\mathrm{Fe}$ & & & & $0.829^{* *}$ & 0.303 & 0.510 & $0.746^{* *}$ & $0.588^{*}$ \\
\hline $\mathrm{K}$ & & & & & 0.212 & 0.516 & 0.560 & 0.352 \\
\hline $\mathrm{Mn}$ & & & & & & 0.551 & 0.468 & $0.675^{*}$ \\
\hline $\mathrm{Cu}$ & & & & & & & 0.517 & $0.622^{*}$ \\
\hline $\mathrm{Zn}$ & & & & & & & & $0.883^{* *}$ \\
\hline
\end{tabular}

\section{Discussion}

Nutrition affects egg quality, so differences in the mineral composition of the egg can be associated with the mineral composition of the diet. Minerals in the animal body affect the egg quality. Poor quality eggs caused by poor eggshell formation, softshells, and cracked shells cause great economic loss. The economic loss arising from the low eggshell quality is the main problem in poultry farming. Mineral contents of eggs reflect the nutrition and health status of laying. The higher the serum calcium level, the higher the calcium level in the eggshell. The aim of this study was to investigate the effects of dietary supplementation with $\mathrm{CaB}_{4} \mathrm{O}_{7}(300 \mathrm{mg} / \mathrm{kg})$ on the mineral content of egg and eggshell in layer quails $[24,25]$.

$\mathrm{B}$ plays a role in calcium metabolism and seems to improve the absorption of $\mathrm{Ca}$ and $\mathrm{Mg}$ [13]. $\mathrm{CaB}_{4} \mathrm{O}_{7}$ addition $\mathrm{a}_{300}$ $\mathrm{mg} / \mathrm{kg}$ ) to a basal diet did not affect edible parts of eggs mineral of $\mathrm{Ca}, \mathrm{Fe}, \mathrm{Mn}, \mathrm{Cu}$, and $\mathrm{Zn}$ in laying quails. Fe had the strongest correlation with $\mathrm{Mn}$ in whole egg. $\mathrm{CaB}_{4} \mathrm{O}_{7}$ supplementation at $300 \mathrm{mg} / \mathrm{kg}$, to a diet, increased $\mathrm{Mg}$, $\mathrm{Na}$, and $\mathrm{K}$ contents of whole edible parts of eggs. In the present study, whole edible parts of eggs B concentration were not determined for laying quails. However, Sizmaz and Yildiz [26] reported that supplementation of $120 \mathrm{mg} / \mathrm{kg}$ boric acid (includes $17.5 \%$ B) significantly affected liver and egg yolk B contents. Moreover, Kucukyilmaz and Erkek [27] observed a significant increase in B content of edible parts of eggs in laying hens fed diets supplemented with B. There is no study investigating the effect of $B$ addition to the diet on other minerals except B in the edible part of the egg. 
Minerals such as Ca, P and vitamin D are the primary factors affecting eggshell quality of layers [24]. Zinc has been associated with carbonic anhydrase enzyme and in improving eggshell quality. Also, a deficiency of copper can causes shell abnormalities [28]. This all minerals improves the quality of the shell. These results suggested that $\mathrm{CaB}_{4} \mathrm{O}_{7}$ supplementation positively effects eggshell mineral content. The correlation between B and $\mathrm{Zn}$ was high and positive in eggshell. In the current study, B concentration was detected in eggshell, while it was not detected in the whole eggs of both groups. $\mathrm{B}, \mathrm{Mg}, \mathrm{Na}, \mathrm{Fe}, \mathrm{K}, \mathrm{Cu}$ and $\mathrm{Zn}$ was higher in eggshells of the additive group than in control. In contrast, Bintas ve Ozdogan [29], who observed that supplementation of B (100 mg/kg) to laying hens diet did not affect the Ca, P, and B levels of eggshell. Our results were consistent with are in accordance with those of Arslan Kaya and Macit [30], who reported that supplementation of B (orthoboric acid, $150 \mathrm{mg} / \mathrm{kg}$ ) into the diet caused an increase in B and Ca contents of eggshells, and a decrease in Fe contents of eggshells. Also, the $\mathrm{Zn}, \mathrm{Mg}, \mathrm{Mn}$, and $\mathrm{Na}$ contents of eggshells were not affected by the B addition. Similarly, El-Saadany et al., [31] stated that the dietary B supplementation significantly increased eggshell calcium and boron concentrations. These results are in correspondence with the finding of Mizrak et al., [32] and Mizrak and Ceylan [33], they reported that the supplementation of B increased Ca and B in eggshell. This may be due to B effects on metabolism Ca, P, Mg and vitamin D which improves eggshell quality [31]. These results can be associated with animal age, mineral level of basal ration, B dose, source, and form [30].

\section{Conclusion}

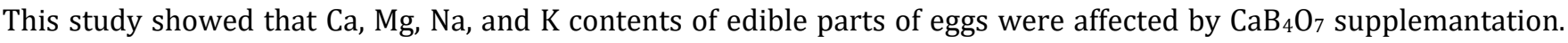
Moreover, $\mathrm{CaB}_{4} \mathrm{O}_{7}$ supplementation in layer diets might be a positive effect on calcium metabolism, producing eggs enriched in minerals, promoting $\mathrm{B}, \mathrm{Mg}, \mathrm{Na}, \mathrm{Fe}, \mathrm{K}, \mathrm{Cu}$ and $\mathrm{Zn}$ deposition in eggshells, and improving eggshell quality. Further study should be conducted to evaluate the effective B supplementation doses for functional egg production and usage of B could be advantageous in terms of beneficial health effects.

\section{Compliance with ethical standards}

\section{Acknowledgments}

The authors thank the Turkish Energy, Nuclear, and Mining Research Authority Boron Research Institute.

\section{Disclosure of conflict of interest}

The authors report no conflicts of interest.

\section{Statement of ethical approval}

This study was approved by the Local Ethics Committee of Firat University, Elazig, Turkey (2020/11).

\section{References}

[1] Cetin S, Gurcan S. Kahverengi ve beyaz yumurtacı hibrit tavuk yemlerine istiridye kabuğu ilavesinin yumurta kabuk kalitesine ve serum kalsiyum düzeyine etkileri. Lalahan Hayvancılık Araştırma Enstitüsü Dergisi. 2006; 46(2): 23-31.

[2] Wang J, Um P, Dickerman BA, Liu J. Zinc, magnesium, selenium and depression: A Review of the evidence, potential mechanisms and implications. Nutrients. 2018;10: 584.

[3] Spencer T. Pastured poultry nutrition and forages. National Sustainable Agriculture Information Service; (C) 2013 [cited 2021 February 24].

[4] Surai PF. Selenium in poultry nutrition: a new look at an old element. 2. Reproduction, egg and meat quality and practical applications. World's Poultry Science Journal. 2002; 58: 431-450.

[5] Fisinin VI, Papazyan TT, Surai PF. Producing specialist poultry products to meet human nutrition requirements selenium enriched eggs. World's Poultry Science Journal. 2008; 64: 85-98.

[6] Heflin LE, Malheiros R, Anderson KE, Johnson LK, Raatz SK. Mineral content of eggs differs with hen strain, age, and rearing environment. Poultry Science. 2118; 0: 1-9.

[7] Kralik G, Kralik Z, Grčević M, Kralik İ, Gantner V. Enrichment of table eggs with functional ingredients. Journal of Central European Agriculture. 2018; 19(1): 72-82. 
[8] Spasevski NJ, Peulić TA, Banjac TV, Rakita SM, Pezo LL, Čolović RR, Basić ZN. Natural additives in functional egg production. Food and Feed Research. 2019; 46(2):199-207.

[9] Kılıc AM, Kılıc O, Andac I, Celik AG. Boron mining in Turkey, the marketing situation and the economical importance of Boron in the World. IV International boron symposium. Eskişehir-TURKEY. 15-17 October.

[10] Kabu M, Civelek T. Effects of propylene glycol, methionine and sodium borate on metabolic profile in dairy cattle during periparturient period. Revue de Médecine Vétérinaire. 2012; 163(8-9): 419-430.

[11] Hunt CD. One possible role of dietary boron in higher animals and humans. Biological Trace Element Research. 1998; 66: 205-225.

[12] Yesilbag D, Eren M. Effects of dietary boric acid supplementation on performance, eggshell quality and some serum parameters in aged laying hens. Turkish journal of veterinary and animal sciences. 2008; 32: $113-117$.

[13] Abdelnour SA, Abd El-Hack ME, Ayman Swelum AA, Perillo A, Losacco C. The vital roles of boron in animal health and production: A comprehensive review. Journal of Trace Elements in Medicine and Biology. 2018; 50: 296-304.

[14] Nielsen F. Historical and recent aspects of boron in human and animal health. Journal of Boron. 2017; 2(3): 153160.

[15] Devirian TA, Volpe SL. The physiological effects of dietary boron. Critical Reviews in Food Science and Nutrition. 2003; 43(2): 219-231.

[16] NRC. Nutrient Requirements of Poultry. 9th ed. Washington DC: National Academy Press; 1994.

[17] Crampton EW, Maynard LA. The relation of cellulose and lignin content to 21 nutritive values of animal feeds. The Journal of Nutrition. 1938; 15: 383-395.

[18] Carpenter KJ, Clegg KM. The metabolizable energy of poultry feeding stuffs in relation to their chemical composition. Journal of the Science of Food and Agriculture. 1956; 7: 45-51.

[19] AOAC. Official Methods of Analysis. 17th ed. USA: Gaithersburg-MD. 2000.

[20] Iflazoglu S, Yilmaz A, Kafadar VE, Yazici AN. Investigation of neutron sensitivity of un-doped and Dy-doped $\mathrm{CaB}_{4} \mathrm{O}_{7}$ for thermoluminescence applications. Journal of Thermal Analysis and Calorimetry. 2018; 133: 13271333.

[21] US EPA. Method 3051A (SW-846): Microwave assisted acid digestion of sediments, sludges, and oils, Washington DC: Revision. 2007; 1.

[22] US EPA. Method 6010D (SW-846): Inductively coupled plasma-atomic emission spectrometry," Washington DC: Revision. 2014; 4.

[23] IBM Corp. Released IBM SPSS Statistics for Windows, Version 21.0. Armonk, NY, USA. 2012.

[24] Attia YA, Al-Harthi MA, Shiboob MM. Evaluation of quality and nutrient contents of table eggs from different sources in the retail market. Italian Journal of Animal Science. 2014; 13: 3294.

[25] Stanquevis CE, Furlan AC, Marcato SM, Oliveira-Bruxel TM, Perine TP, Finco EM, Grecco ET, Benites MI, Zancanela VT. Calcium and available phosphorus requirements of Japanese quails in early egg-laying stage. Poultry Science. 2021; 100: 147-158.

[26] Sizmaz 0, Yildiz G. Influence of dietary boric acid and ascorbic acid on performance, egg traits, cholesterol and bone parameters of laying hens. Ankara Üniversitesi Veteriner Fakültesi Dergisi. 2016; 63: 151-156.

[27] Kucukyilmaz K, Erkek R. Farklı düzeylerde kalsiyum ve fosfor içeren yumurta tavuğu karma yemlerine bor ilavesinin yumurta mineral içerikleri üzerine etkileri. Adnan Menderes Üniversitesi Ziraat Fakültesi Dergisi 2012; 9(1): 33-38.

[28] Siulapwa N, Mwambungu A, Mubbunu L. Comparison of mineral composition of commercial hen egg shells to fresh water crocodile egg shells. International Journal of Research in Agriculture and Food Sciences. 2014; 2(7): 2311-2476.

[29] Bintas E, Ozdogan M. Bor ve zeolit içeren yemlerin yaşlı yumurtacı tavuklar üzerine etkileri. Tekirdağ Ziraat Fakültesi Dergisi. 2017; 14(02).

[30] Arslan Kaya H, Macit M. Yumurtlamanın son dönemindeki yumurtacı tavukların rasyonlarına bor (ortoborik asit) ilavesinin yumurta kabuk kalitesi ve tibia biyomekaniği parametreleri ile serum, kabuk ve tibia mineral konsantrasyonları üzerine etkisi. Atatürk Üniversitesi Veteriner Bilimleri Dergisi 2018; 13(1): 42-53. 
[31] El-Saadany AS, Shreif EY, EL-Barbary AM. The influence of dietary boron supplementation on performance and some physiological parameters in bandarah chickens 2- laying period. Egyptian Poultry Science Journal. 2017; 37(1): 105-122.

[32] Mizrak C, Yenice E, Can M, Yildirim U, Atik Z. Yumurta tavuğu karma yemlerine farklı düzeylerde bor ilavesinin performans, yumurta kalitesi ve kemik gelişimi üzerine etkileri. 2. Ulusal Bor Çalıştayı. 2008; 605-612.

[33] Mizrak C, Ceylan N. Effects of organic boron supplementation into layer breeder diets on egg quality. International Egg Symposium the Return of the Good egg. Istanbul. 2008; 176-186. 